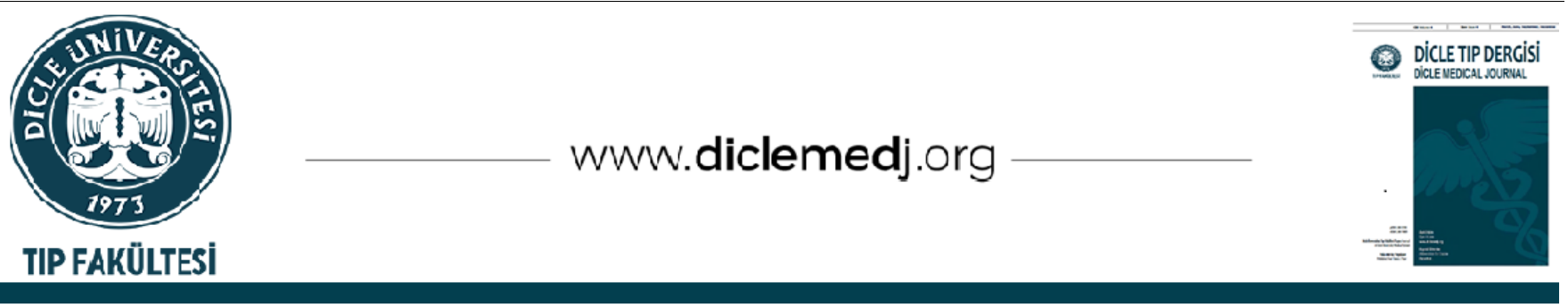

Original Article / Özgün Araştırma

\title{
Factors Associated With Hospitalisation of Copd Exacerbations During a Winter Season In an Emergency Ward
}

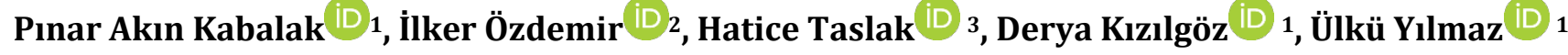 \\ 1 Atatürk Chest Disease and Thoracic Surgery Education and Research Hospital, Ankara, Turkey \\ 2 Suat Seren Chest Disease and Thoracic Surgery Education and Research Hospital, Izmir Turkey \\ 3 Ministry of Health, Ankara City Hospital, Ankara, Turkey
}

Received: 20.08.2020; Revised: 31.03.2021; Accepted: 04.04.2021

\begin{abstract}
Objectives: Chronic obstructive pulmonary disease (COPD) is a difficult chronic illness to manage because it causes prolonged hospital admissions and repeated applications. We aimed to examine the factors affecting this situation in a winter emergency in a chest diseases emergency. Material and Method: We conducted a retrospective study in our emergency department (ED) with patients who admitted due to COPD exacerbations. Factors affecting hospitalization and ICU requirement were evaluated.

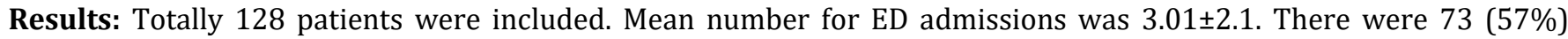
hospitalized patients and 17(13.3\%) patients transferred to intensive care unit (ICU). White blood cell (WBC) and C reactive protein (CRP) were significantly higher in patients with $\geq 3$ ED admissions than others $(p=0.06$ and $p=0.007$ respectively). Among categorical variables being current smoker, long time oxygen therapy (LTOT) and non-invasive mechanical ventilation (NIMV) devices and existence of bronchiectasis were related to frequent ED admission ( $p=0.025$, $\mathrm{p}=0.01, \mathrm{p}=0.046$ and $\mathrm{p}=0.028$ respectively). Existence of pneumonia and comorbidities had positive and significant correlations with hospitalization ( $\mathrm{r}=0.18, \mathrm{p}=0.04$ and $\mathrm{r}=0.26, \mathrm{p}=0.02)$. In terms of ICU requirement, pneumonia, partial arterial pressure of carbon dioxide (PaCO2) value and mean pulmonary arterial pressure (PAB) had significant correlations ( $\mathrm{r}=0.27, \mathrm{p}=0.001, \mathrm{r}=0.34, \mathrm{p}<0.001$ and $\mathrm{r}=0.24, \mathrm{p}=0.006$ respectively).
\end{abstract}

Conclusion: The correct man.944321agement of the identified factors associated with recurrent emergency admission, service and ICU hospitalization in COPD patients should be done both at home and in the hospital.

Keywords: COPD exacerbations, hospitalization, related factors

DOI: 10.5798/dicletip.944321

Correspondence / Yazışma Adresi: Pınar Akın Kabalak, Ankara Atatürk Chest Disease and Thoracic Surgery Education and Research Hospital, Department of Chest Disease, Ankara, Turkey, 06290 e-mail: pinarakinn@yahoo.com 


\section{Bir Kiş Döneminde Acile Koah Atak ile Başvuran Olgularin Yönetimi ve Hastane Yatişi İlişkili Faktörler}

Öz

Giriş: Kronik obstrüktif akciğer hastalığı (KOAH), tekrarlayan acil başvurusu ve uzamış hastane yatışlarına neden olduğu için tedavisi zor bir kronik hastalıktır. Bir kış döneminde göğüs hastalıkları acilinde KOAH atak seyrini etkileyen faktörleri incelemeyi amaçladık.

Yöntemler: KOAH alevlenmeleri nedeniyle acil servisimize başvuran olgularla retrospektif bir çalışma gerçekleştirdik. Sık acil başvurusu, hastaneye yatış ve yoğun bakım ünitesi (YBÜ) gerekliliğini etkileyen faktörler değerlendirildi.

Bulgular: Toplam 128 hasta dahil edildi. Ortalama acil başvuru sayısı $3.01 \pm 2.1$ idi. Hastaların 73'ü (\% 57) hastaneye yatırıldı ve 17'si (\% 13.3) YBÜ transfer edildi. Beyaz küre ve C-reaktif protein (CRP), 3 den fazla acil başvurusu olan hastalarda diğerlerine kıyasla anlamlı olarak yüksekti ( $p=0.06$ ve $p=0.007$ sırasıyla). Aktif sigara kullanımı, uzun süreli oksijen tedavisi (USOT) ve non-invaziv mekanik ventilasyon (NIMV) cihazları ve bronşektazi varlığı sık acil başvurusu ile ilişkili saptandı (Sırasıyla $p=0.025, p=0.01, p=0.046$ ve $p=0.028$ ). Zatürree ve komorbiditelerin yatış ile pozitif ve anlamlı korelasyonları vardı $(r=0.18, p=0.04$ ve $r=0.26, p=0.02)$. Yoğun bakım gereksinimi açısından pnömoni, Parsiyel arteriyel karbondioksit basıncı (PaCO2) değeri ve ortalama pulmoner arter basıncı (PAB) arasında anlamlı korelasyonlar vardı (Sirasıyla $r=0.27, p=0.001 ; r=0.34, p<0.001$ ve $r=0.24, p=0.006$ ).

Sonuç: KOAH hastalarında tekrarlayan acil başvuru, servis ve YBÜ yatışılla ilişkili tanımlanmış faktörlerin doğru yönetimi hem evde hem de hastanede yapılmalıdır.

Anahtar kelimeler: KOAH atak, hastane yatışı, ilişkili faktörler.

\section{INTRODUCTION}

Chronic obstructive pulmonary disease (COPD) is a serious public health problem that affects approximately three million people worldwide and disrupts the quality of life. Even it is preventable and treatable, unfortunately it is expected one of most common cause of death in $2020^{1}$. Acute exacerbation of COPD (AECOPD), is a serious cause of mortality and morbidity as it causes disease progression, imposes significant financial burden and increases hospitalization ${ }^{1}$.

In a study of short and long-term mortality including 890 patients, old age, poor nutritional status, long length of hospitalization, cardiovascular disorders, lung cancer, low lymphocyte count and hypercapnia were independent risk factors ${ }^{2}$. According to the prospective-cohort study of Steirade et al., discharging with long-term oxygen therapy (LTOT), forced expiratory volume in first second (FEV1) and body mass index (BMI) were associated with prognosis in patients with
COPD exacerbations requiring non-invasive mechanical ventilation (NIMV) ${ }^{3}$. Mortality regarding treatment strategies revealed that having a single drug prescribe at discharge and having more than 2 severe exacerbations are related to poor prognosis 4 . In a study examining the importance of serum biomarkers in COPD exacerbations, it was found that high procalcitonin levels were associated with mortality and length of hospital stay5.

Burden of AECOPD can differs according to severity of exacerbations. Study assessing healthcare utilization according to type of acute COPD exacerbation revealed that healthcare utilization was significantly higher among patients with more severe COPD. These group of patients can be defined as they make the most frequent referrals in the emergency departments (ED) ${ }^{6}$. In this case, the economic burden of COPD attack that is a chronic condition comes to mind. According to an economic burden study that includes data from Asia (including Turkey), Europe and America, 
hospitalization cost is $\$ 6852$ for USA, $\$ 1031$ for Turkey ${ }^{7}$. Severity of COPD and frequency of exacerbation are most influencing factors on increasing $\operatorname{costs}^{8}$. So it is important to prevent exacerbations.

So we aimed to retrospectively analyse what factors are related to length of stay in hospital after an AECOPD for a winter period in an emergency ward of a chest disease hospital.

\section{METHOD}

Data was retrospectively collected using hospital data base. Information of patients (with/without hospitalization) who admitted to ED, between October 2014 - March 2015 in our hospital were used. Demographic data were age, gender, smoking status, comorbidities, existence of NIMV device or LTOT. Number of ED admissions, length of stay in hospital, intensive care unit (ICU) requirement were recorded. Probable related factors like, pneumonia, bronchiectasis, pulmonary hypertension, white blood cell account (WBC), neutrophil account and C-reactive protein (CRP) level were considered. Number of ED admission and hospitalization were recorded and median time of length of hospitalization (day) was calculated by dividing the total length of hospitalization by the number of applications. Study was approved by hospital local ethical committee with number of 472/23.7.2014

\section{Statystical Analyses}

SPSS Inc. Released 2009. PASW Statistics for Windows, Version 18.0. Chicago: SPSS Inc. was used for the database and statistical analyses. Demographic features of study were analysed with descriptive statistics. For continuous variables means (standard deviation [SD]) were used, whereas categorical variables were reported as the absolute number and percentage. To compare non-parametric variables of patients according to number of ED admissions (Table 2) and analysis of variables in terms of hospitalization and ICU requirement (Table 3),
Chi-Square Tests and for parametric variables student-t test were used. Spearmen correlation analyses was used to predict factors associated with ED admission, hospitalization and ICU need. Value of $p<0.05$ was accepted as statistically significant.

\section{RESULTS}

A total of 128 patients with COPD visited to ED. Most of whom were male $(\mathrm{n}=112,87.5 \%$, female $\mathrm{n}=16,12.5 \%$ ) with mean age of $68.6 \pm 10.2$. Of the 112 patients whose smoking status was available, $74(67.2 \%)$ had former, 15 (13.3\%) were current smoker and 23 (20.5\%) had never smoked during their lifetime. Fifty-five patients $(42.9 \%)$ were already had LTOT and 18 patients (14\%) had their home type non-invasive mechanical ventilator (NIMV). 80\% of the patients had at least one comorbidity. The majority of these comorbidities were congestive heart failure (CHF) $(26 \%)$ and coronary arterial disease (CAD) (28\%).

Mean number for ED admissions was 3.01 \pm 2.1 . Number of patients whose emergency service visit ended with hospitalization was 73 (57\%) and number of patients transferred to intensive care unit (ICU) directly from the emergency department or inpatient clinics was 17 cases (13.3\%). Mean time (day) for hospitalization was $11.8 \pm 7.9$ and $20.3 \pm 13.6$ for staying in ICU (Figure 1).

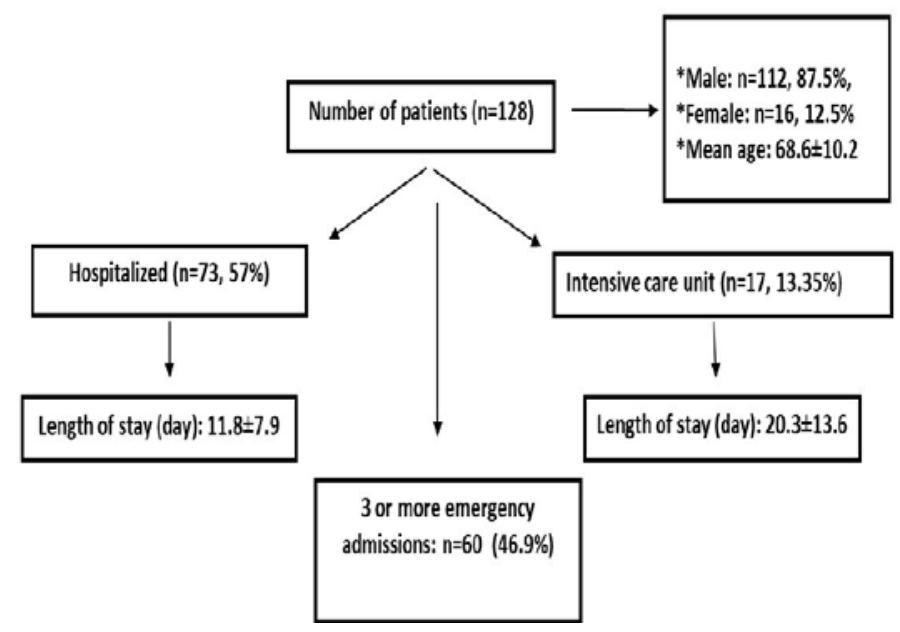

Figure 1. Flow chart demonstrating in which department and how many day patients received treatment 
Initial values of some laboratory findings were recorded. Mean value for WBC was $11.4 \pm 4.8$, $8.9 \pm 4.5$ for neutrophil and $3.7 \pm 3.6$ for CRP. There were 62 patients having arterial blood gas analysis. Mean value for partial pressure of oxygen $(\mathrm{PaO} 2)$ was $55.9 \pm 14.7,46.9 \pm 13.4$ for partial pressure for carbon dioxide $(\mathrm{PaCO} 2)$ and $7.37 \pm 0.14$ for ph. Mean pulmonary arterial pressure (PAB) was 43.1 \pm 10.5 . Demographic and laboratory findings were summarized in Table 1.

Table I: Demographic features of study population

\begin{tabular}{|c|c|c|}
\hline Variables & $\mathrm{N} / \%$ & Mean (SD) \\
\hline Gender & & \\
\hline Male & $112(87.5 \%)$ & \\
\hline Female & $16,(12.5 \%)$ & \\
\hline Age & & $68.6 \pm 10.2$ \\
\hline$\underline{\text { Smoking status }} \mathbf{1}$ & & \\
\hline Former smoker & $74,67.2 \%$ & \\
\hline Current smoker & $15,13.3 \%$ & \\
\hline Never smoked & $23,20.5 \%$ & \\
\hline LTOT $^{2}$ & $55,42.9 \%$ & \\
\hline LTNIMV3 & $18,14 \%$ & \\
\hline White blood cell & & $11.4 \pm 4.8$ \\
\hline Neutrophil & & $8.9 \pm 4.5$ \\
\hline CRP & & $3.7 \pm 3.6$ \\
\hline $\begin{array}{l}\text { Artery blood gas } \\
\text { analyses } \\
\mathrm{PaO} 2 \\
\mathrm{PaCO} 2 \\
\mathrm{Ph}\end{array}$ & & $\begin{array}{l}55.9 \pm 14.7 \\
46.9 \pm 13.4 \\
7.37 \pm 0.14\end{array}$ \\
\hline $\mathrm{mPAB}^{5}$ & & $43.1 \pm 10.5$ \\
\hline
\end{tabular}

1 Smoking information of 112 patients was available

2 Long term oxygen therapy

3 Long term non-invasive mechanical ventilation

4 Number of patients requiring arterial blood gas was 62 patients

5 Mean pulmonary arterial pressure
Number of patients with 3 or more emergency admissions was 60 patients (46.9\%, Figure 1). When compared two groups WBC and CRP were significantly higher in group of patients with 3 or more ED admissions than patients lower than 3 admissions $(n=68,53.1 \%) \quad(p=0.06$ and $\mathrm{p}=0.007$ respectively). Among categorical variables being current smoker, having their LTOT and NIMV devices at home and existence of bronchiectasis were related to 3 or more ED admission $(\mathrm{p}=0.025, \mathrm{p}=0.01, \mathrm{p}=0.046$ and $\mathrm{p}=0.028$ respectively, Table 2 ).

Table II: Comparison of patients according to number of ED admissions

\begin{tabular}{|c|c|c|c|}
\hline Variables & $\begin{array}{l}\geq 3 \\
\text { admission } \\
(n=60,46.9 \%)\end{array}$ & $\begin{array}{l}<3 \\
\text { admission } \\
n=68,53.1 \%\end{array}$ & P value \\
\hline White blood cell & $12.6 \pm 5.4$ & $10.3 \pm 3.9$ & 0.06 \\
\hline CRP & $4.7 \pm 4.5$ & $3.02 \pm 2.5$ & 0.007 \\
\hline Neutrophil & $10.1 \pm 5.1$ & $7.9 \pm 3.7$ & 0.15 \\
\hline Current smoker & 12 & 3 & 0.025 \\
\hline LTOT $^{1}$ & 33 & 22 & 0.01 \\
\hline LTNIMV2 $^{2}$ & 13 & 5 & 0.046 \\
\hline Bronchieactasis & 26 & 17 & 0.028 \\
\hline
\end{tabular}

${ }^{2}$ Long term non-invasive mechanical ventilation

There were 73 (57\%) hospitalized after ED admission and the presence of pneumonia, existence of co morbidity were significant factors that may be related to hospitalization after emergency admission $(\mathrm{p}=0.039$ and $\mathrm{p}=0.015$, Table 3). Again, according to correlation analyses pneumonia and comorbidities had positive and significant correlations $(r=0.18, p=0.04$ and $r=0.26$, $\mathrm{p}=0.02$ ). 
Table III: Analysis of variables in terms of hospitalization and ICU requirement

\begin{tabular}{|c|c|c|c|}
\hline Variables & $\begin{array}{l}\text { Hospitalization } \\
(n=73)\end{array}$ & $\begin{array}{l}\text { No } \\
\text { Hospitalization } \\
(n=55)\end{array}$ & $p$ value \\
\hline Pneumonia & 22 & 8 & 0.03 \\
\hline Co-morbidity & 65 & 38 & 0.01 \\
\hline White blood cell & 11.4 & 11.3 & 0.87 \\
\hline CRP & 4.0 & 3.4 & 0.40 \\
\hline Neutrophil & 9.0 & 8.7 & 0.70 \\
\hline LTOT & 35 & 20 & 0.12 \\
\hline LTNIMV & 11 & 7 & 0.62 \\
\hline Bronchieactasis & 22 & 21 & 0.22 \\
\hline \multirow[t]{2}{*}{$\begin{array}{ll}\text { Mean } & P A B>25 \\
m m H g & \end{array}$} & 51 & 25 & 0.37 \\
\hline & $\begin{array}{l}\text { ICU } \\
\text { Requirement } \\
(n=17)\end{array}$ & $\begin{array}{l}\text { No ICU } \\
\text { Requirement } \\
(n=111)\end{array}$ & p value \\
\hline Pneumonia & 9 & 21 & 0.005 \\
\hline Co-morbidity & 11 & 43 & 0.04 \\
\hline White blood cell & 12.5 & 11.2 & 0.33 \\
\hline CRP & 3.1 & 3.9 & 0.46 \\
\hline Neutrophil & 9.9 & 8.8 & 0.38 \\
\hline Bronchieactasis & 4 & 39 & 0.27 \\
\hline mPAB & 49.7 & 41.8 & 0.01 \\
\hline PcO2 & 57.5 & 43.8 & $<0.01$ \\
\hline
\end{tabular}

${ }^{1}$ Long term oxygen therapy

${ }^{2}$ Long term non-invasive mechanical ventilation

Number of patients requiring ICU was 17 (13.3\%). In ICU group while 8 of them were transferred from inpatient services and 9 patients were directly taken from ED. Mean PAB and $\mathrm{PaCO} 2$ value and number of patients with pneumonia were significantly higher in patients requiring ICU than others do not $(p=0.012$, $\mathrm{p}=0.002$ and $\mathrm{p}<0.001$ respectively, Table 3 ). In correlation analyses pneumonia, $\mathrm{PaCO} 2$ value and mean $\mathrm{PAB}$ had significant correlations $(\mathrm{r}=0.27, \mathrm{p}=0.001, \mathrm{r}=0.34, \mathrm{p}<0.001$ and $\mathrm{r}=0.24$, $\mathrm{p}=0.006$ respectively).

\section{DISCUSSION}

Exacerbation of COPD and requirements of hospitalization cause serious economic and social burden. Moreover, this burden increases exponentially with the severity of the disease, increase in attack frequency and need of ICU7. It is well known that $>2$ exacerbations in the previous year is a risk for new exacerbations and hospitalization ${ }^{9}$. In current study we did not study on economic burden of COPD, however there were 73 hospitalized patients, 17 ICU requirement and although study covers a short time interval, there were 60 patients (46.9\%). with 3 or more emergency admissions. In other words, it is noteworthy that there are many repeated applications in the risky months for COPD attack.

A study with 219 COPD patients revealed the mean \pm standard deviation (SD) number of exacerbations in the year prior to admission was 2.1 (1.7) for mild to moderate exacerbations, $0.9 \quad$ (1.3) for severe exacerbations and one hundred sixty-one patients (74\%) were hospitalized. Also they have reported no unnecessary admission ${ }^{10}$. Mean number for ED admissions was 3.01 \pm 2.1 in our study, a little higher. When we look at the gender distribution, it was similar for both studies with male predominance. Again, the smoking behaviour pattern is similar in both studies. Unlike other study, we did not include asthma /COPD overlap cases in the study. This may be one of the reasons that make the difference in the average number of applications. Frequency of hospitalized patients were lower in our study (57\%) than existing report. Because there were 55 (42.9\%) patients with LTOT. So after initial assessment in ED, according to patients' response to attack treatments, we tend to discharge directly from the ED with prescribing necessary drugs (bronchodilators, antibiotics or oral metilprednisolon for couple of days) to home and alert patients to come early visit in outpatient 
clinics. Indeed, there is a report that effective treatment and observations of adequate time in the emergency observation unite has also been shown to decrease repeat admissions ${ }^{11}$.

Existence of comorbidity and pneumonia were related with hospitalization with significance $(p=0.01)$. That means, initial treatments in ED observation unite had failure and prolonged length of stay in hospital. Similarly, according to retrospective study including 220 COPD patients, comorbidities like arrhythmias, diabetic mellitus and pneumonia findings on chest X-ray were factors associated to treatment failure ${ }^{12}$.

When compared two groups ( $\geq 3$ ED admission vs. $<3$ ED admission) increased CRP level, active smoking, existence of bronchiectasis and using LTOT/LTNIMV are related factors with significance in our study. Similarly, a metaanalyses revealed that bronchiectasis end LTOT are predictive factors for readmissions ${ }^{13}$.

Several studies revealed that $6-10 \%$ of COPD patients with exacerbations transferred to an ICU from medical wards ${ }^{14,15}$. Pneumonia, comorbidity, Pco2 were had positive correlation in terms of ICU requirement in our study. Our results were in consists with a recent study including 374 patients. Frequency of patients with comorbidity, pneumonia was higher in ICU group than medical ward. Also mean value of Pco2 was higher in ICU unite like current study ${ }^{16}$.

Although there are guidelines on COPD attack management, success in treatment depends on both the physician's approach and the facilities of the health center ${ }^{17}$.

Study has some limitations that stage of COPD, drugs (inhaler medications) that patients used during stable period were not recorded. Also it was not possible to retrospectively evaluate how adequately and correctly the patients use their devices (LTOT or NIMV).

\section{CONCLUSION}

COPD is a chronic disease that causes a massive burden on the health system. Careful follow-up of many clinical, radiological and laboratory parameters is required at every stage from the long-term home treatment phase to the emergency room, inpatient service and ICU process.

Ethics Committee Approval: Study was approved by hospital local ethical committee with number of 472/23.7.2014

Declaration of Conflicting Interests: The authors have no conflict of interests to declare.

Financial Disclosure: The authors declared that this study has received no financial support.

\section{REFERENCES}

1. Global Initiative for Chronic Obstructive Lung Disease (GOLD). Global strategy for the diagnosis, management, and prevention of chronic obstructive pulmonary disease (2019 report) [Internet]. EUA: GOLD; 2019 [cited 2018 Dec 7]. Available from: https://goldcopd.org/wpcontent/uploads/2018/11/GOLD-2019-v1.7FINAL-14Nov2018-WMS.pdf.

2. Zhang Y, Lin YX. Risk factors analysis for one-year and long-term mortality in patients hospitalized for acute exacerbation of chronic obstructive pulmonary disease. Zhonghua Jie He He Hu Xi Za Zhi. 2019; 42: 895-900.

3. Steriade AT, Davidoiu A, Afrasinei A, et al. Predictors of Long-term Mortality after Hospitalization for Severe COPD Exacerbation. Maedica (Buchar). 2019; 14: 86-92.

4. Casas-Mendez F, Abadías MJ, Yuguero 0, et al. Treatment strategies after acute exacerbations of chronic obstructive pulmonary disease: Impact on mortality. PLoS One. 2018; 12: e 0208847.

5. Civelek C, Korkmaz İ, Eren ŞH, et al. Kronik obstruktif akciğer hastalığı akut alevlenmeli hastalarda prokalsitonin ve diğer akut faz belirteçleri. Dicle Tip Derg. 2011;38: 137-42. 
6. Overbeek JA, Penning-van Beest FJ, Balp MM, et al. Burden of Exacerbations in Patients with Moderate to Very Severe COPD in the Netherlands: A Real-life Study. COPD. 2014; 12: 132-43.

7. Rehman AU, Ahmad Hassali MA, et al. The economic burden of chronic obstructive pulmonary disease (COPD) in the USA, Europe, and Asia: results from a systematic review of the literature. Expert Rev Pharmacoecon Outcomes Res. 2019; 18: 1-12.

8. Kim J, Rhee $\mathrm{CK}$, Yoo $\mathrm{KH}$, et al. The health care burden of high grade chronic obstructive pulmonary disease in Korea: analysis of the Korean Health Insurance Review and Assessment Service data. Int J Chron Obstruct Pulmon Dis. 2013; 8: 561-8.

9. Hurst JR, Vestbo J, Anzueto A, et al. Evaluation of COPD Longitudinally to Identify Predictive Surrogate Endpoints (ECLIPSE) Investigators. Susceptibility to exacerbation in chronic obstructive pulmonary disease. N Engl J Med. 2010; 363: 112838.

10. Abadias Medrano MJ, Torres OY, Robles IB, et al. Exacerbations of chronic obstructive pulmonary disease. An analysis of the care process in a regional hospital emergency department. Medicine 2018;97: e11601

11. Budde J, Agarwal P, Mazumdar M, et al. Can an Emergency Department Observation Unit Reduce Hospital Admissions for COPD Exacerbation? Lung. 2018; 196: 267-0.
12. Pethyabarn W, Chewae S, Dadeh AA. Factors Associated with Treatment Failure in Patients with Acute Exacerbation of COPD Admitted to the Emergency Department Observation Unit. Emerg Med Int. 2020: 8261375.

13. Alqahtani JS, Njoku CM, Bereznicki B, et al. Risk factors for all-cause hospital readmission following exacerbation of COPD: a systematic review and meta-analysis. Eur Respir Rev. 2020; 29: 190166.

14. Groenewegen KH, Schols AM, Wouters EF. Mortality and mortality-related factors after hospitalization for acute exacerbation of COPD. Chest. 2003; 124: 459-67.

15. Ranieri P, Bianchetti A, Margiotta A, et al. Predictors of 6-month mortality in elderly patients with mild chronic obstructive pulmonary disease discharged from a medical ward after acute nonacidotic exacerbation. J Am Geriatr Soc. 2008; 56: 909-13.

16. Shin HJ, Park CK, Kim TO, et al. Different characteristics associated with intensive care unit transfer from the medical ward between patients with acute exacerbations of chronic obstructive pulmonary disease with and without pneumonia. J Thorac Dis. 2016; 8: 1121-31.

17. Satıcı MO, Aksel G, Satıcı C, et al. Adherence of Emergency Medicine Physicians to the GOLD Report in Management of COPD Exacerbation. Anatolian J Emerg Med. 2020; 3; 42-46. 